\title{
Production of biomass and energy stock for five Eucalyptus species
}

\author{
Rodrigo Simetti ${ }^{1 \star}$, Ghislaine Miranda Bonduelle ${ }^{2}$, Dimas Agostinho da Silva ${ }^{2}$, Sandra Lucia Soares \\ Mayer $^{2}$, Huan Pablo Souza ${ }^{3}$, Graciela Inês Bolzón de Muniz ${ }^{2}$ \\ ${ }^{1}$ Departamento de Ciências Florestais, Universidade Federal de Lavras (UFLA), Lavras, MG, Brasil. \\ ${ }^{2}$ Departamento de Engenharia e Tecnologia Florestal, Universidade Federal do Paraná (UFPR), Curitiba, PR, Brasil. \\ ${ }^{3}$ Stora Enso Florestal, Rosário do Sul RS, Brasil.
}

\begin{abstract}
This study assessed the energy quality of different tree compartments (wood, bark, branches and leaves) for bioenergy use. Five species of the genus Eucalyptus were used, in which high heating value, contents of fixed carbon, volatile materials and ash, as well as the production of dry biomass and the amount of energy stored in each of the evaluated compartments, were measured. All evaluated species were able to produce energy, with no significant differences among species. In relation to the compartments, leaves and bark had higher heating value and ash content, respectively. The energy stock per unit area of all species had similar values.
\end{abstract}

Keywords: bioenergy; combustion; heating value.

\section{Produção de biomassa e estoque de energia para cinco espécies de Eucalyptus}

RESUMO O presente trabalho avaliou a qualidade energética dos diferentes compartimentos da árvore (madeira, casca, galhos e folhas) para utilização bioenergética. Foram utilizadas cinco espécies do gênero Eucalyptus, nas quais foram mensurados poder calorifico superior, teor de carbono fixo, materiais voláteis e cinzas, além da produção de biomassa seca e a quantidade de energia estocada em cada um dos compartimentos avaliados. Todas as espécies avaliadas mostraram ser aptas para produção de energia, não havendo diferenças significativas entre as espécies. Em relação aos compartimentos, folhas e casca apresentaram maior poder calorifico superior e maior teor de cinzas, respectivamente. O estoque de energia por unidade de área todas as espécies apresentaram valores semelhantes.

Palavras-chave: bioenergia, combustão, poder calorifico.

\section{Introduction}

The global demand for energy has grown more than 50\% in the last decade and the tendency is that there will be an increase in this demand over time. Wood accounted for $6.3 \%$ of the energy consumed in Brazil in 2014; although the relative wood consumption has declined since the 1970s, total consumption increased (EPE, 2014).

However, the use of wood on a large scale as an energy source requires planting for this specific purpose. In Brazil, several studies have been conducted to make plantations fea- sible for energy purposes (ELOY et al., 2015a, 2015b). It is essential that forest experiments be carried out to understand the relation of biomass and energy production of different species, in order to obtain information that enables the production of wood material.

Eucalyptus plantations stand out among planted forests due to their rapid growth and, therefore, high volumetric productivity, besides being a homogeneous material that is available as an alternative to the use of native wood (RAMOS et al., 2011). The area planted with the genus Eucalyptus in Brazil corresponds to 5.47 million hectares, and it is the most planted forest species, representing $72 \%$ of the total area for 
this purpose (IBÁ, 2015). Of commercial plantations, the biomass left in the field after harvest represents values of 4 to $20 \%$ of the biomass above the soil, depending on several factors such as species, clone, spacing, silvicultural care, environment and site management. This biomass corresponds to tree compartments such as bark, branches and leaves.

Dry biomass, energy stock, high heating value and proximate chemical composition are important properties in evaluation of biomass as fuel. It is necessary to understand how these properties vary between forest species and their compartments. Therefore, this study aims to analyze the effect of the different tree compartments on the energy quality of forest biomass.

\section{Material and Methods}

\section{Study area and sample collection}

The study was conducted on three farms belonging to StoraEnso Florestal - Rio Grande do Sul, located in the municipalities of Alegrete and São Francisco de Assis. The climate of the region is classified as Cfah "Subtropical Mesothermic", constantly humid, according to the Koppen classification, with months of cold weather, frost from May to August, intense heat predominant in January and February. The average temperature of the hottest month is above $22^{\circ} \mathrm{C}$ and the annual average is above $18^{\circ} \mathrm{C}$. Rainfall ranges from $1250 \mathrm{~mm}$ to $1500 \mathrm{~mm}$, with no dry season defined (MALUF, 2000). The soil of the study area is classified as dystrophic red argisol (EMBRAPA, 2006).

Six discs, with approximately $10 \mathrm{~cm}$ height, were taken from the samples: $0 \%(10 \mathrm{~cm}$ of the soil $)$, DAP $(1.30 \mathrm{~m}$ of the soil), $25 \%, 50 \%, 75 \%$ and $100 \%$ with respect to the commercial height of the sample, considered up to the diameter of 6 $\mathrm{cm}$ with bark. At the time of collection, the plants were seven years old
In order to determine the biomass of wood, bark, branch and leaf, the direct method was used, in which clearing and weighing of the different tree compartments are carried out in the field (SANQUETTA, 2002).

Bark and wood were weighed together in the field, and then separated in the laboratory. From each compartment, samples were taken for the determination of moisture content, where the samples were dried in an oven at $103 \pm 2{ }^{\circ} \mathrm{C}$.

For the calculation of biomass per area, the methodology proposed by Santana et al. (2008) was used, in which the average dry biomass of each compartment of the nine trees sampled per species is multiplied by the number of samples per hectare.

\section{Analysis procedure}

The material dried in an oven for $24 \mathrm{~h}$ at $103^{\circ} \mathrm{C}$ was sent for determination of high heating value, according to NBR 8633 (ABNT, 1984), in an adiabatic calorimeter pump (IKA WERKE C5000); and determination of proximate chemical composition, according to NBR 8112 (ABNT, 1986), in which the contents of fixed carbon, volatile materials and ash are determined.

The energy stock (ES), in Mcal, was calculated for each compartment by Equation 1:

$$
E S=B I O * H H V * 10^{3}
$$

Where, ES = Energy stock (Mcal); BIO = Dry biomass of the compartment $(\mathrm{kg}) ; \mathrm{HHV}=$ High heating value of the compartment $\left(\mathrm{kcal} \mathrm{kg}^{-1}\right)$.

As for the biomass estimate per area, the energy stock per hectare was calculated by multiplying the average of the nine trees sampled by the number of samples per hectare.

In the evaluation of the experiment, a completely randomized design was used, in a $5 \times 4$ factorial scheme, with five species (Eucalyptus benthamii, Eucalyptus dunnii, Eucalyptus 
grandis, Eucalyptus saligna and Eucalyptus urophylla $\times$ Eucalyptus grandis) and four tree compartments (wood, bark, branches and leaves), with nine replicates (trees).

Data were submitted to analysis of variance, with a significant effect of the Tukey test, both at $5 \%$ probability, using the software R 3.1.2 (R CORE TEAM, 2014), with the stats package.

\section{Results and Discussion}

In the assessment of high heating value, there was no significant difference for the compartments wood and branches, while bark and leaves showed differences for the factor species. Regarding compartment, the highest average values were found in the leaves, followed by wood and branches, which formed an intermediate group, and the bark was the compartment with the lowest results (Table1).

The mean high heating values observed in wood are higher that reported by Eloy et al. (2015a, 2015b, 2016), but for the bark the mean values are lower. Ash content reduces the calorific value of the fuel and causes reduction on efficiency of burning (VIEIRA et al., 2013). For wood Eucalyptus clones, Botrel et al. (2010) reported ash content $0,11-0,25 \%$ and Dias Junior et al. (2016) reported 1,67 - 2,50 \% for E. grandis and E. saligna.

Table 1. High heating value and proximate chemical composition of the species in the different tree compartments.

Tabela 1. Poder calorifico superior e composição química imediata das espécies nos diferentes compartimentos da árvore

\begin{tabular}{|c|c|c|c|c|c|c|}
\hline & \multirow{2}{*}{ Variable } & \multicolumn{5}{|c|}{ Species } \\
\hline & & E. benthamii & E. dunnii & E. grandis & E. saligna & E. urograndis \\
\hline \multirow{4}{*}{ 豈 } & Wood $^{\text {ns }}$ & $4626 \mathrm{aB}$ & $4660 \mathrm{aB}$ & $4532 \mathrm{aB}$ & $4661 \mathrm{aB}$ & $4585 \mathrm{aB}$ \\
\hline & Bark & $4151 \mathrm{aC}$ & $3986 \mathrm{abC}$ & $3620 \mathrm{cC}$ & $3838 \mathrm{bcC}$ & $3672 \mathrm{cC}$ \\
\hline & Leaves & $5394 \mathrm{bA}$ & $5652 \mathrm{aA}$ & $5206 \mathrm{bcA}$ & $5081 \mathrm{cA}$ & $5074 \mathrm{cA}$ \\
\hline & Branches $^{\text {ns }}$ & $4536 \mathrm{aB}$ & $4566 \mathrm{aB}$ & $4562 \mathrm{aB}$ & $4561 \mathrm{aB}$ & $4504 \mathrm{aB}$ \\
\hline \multirow{4}{*}{ 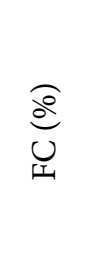 } & Wood $^{\text {ns }}$ & $15.56 \mathrm{aC}$ & $14.80 \mathrm{aB}$ & $14.59 \mathrm{aC}$ & $15.67 \mathrm{aC}$ & $15.14 \mathrm{aC}$ \\
\hline & Bark & $21.83 \mathrm{aA}$ & $19.95 \mathrm{bA}$ & $17.65 \mathrm{cB}$ & $17.12 \mathrm{cC}$ & $20.86 \mathrm{abB}$ \\
\hline & Leaves & $20.55 \mathrm{cB}$ & $20.21 \mathrm{cA}$ & $20.73 \mathrm{bcA}$ & $23.65 \mathrm{aA}$ & $22.21 \mathrm{abA}$ \\
\hline & Branches $^{\text {ns }}$ & $20.99 \mathrm{aAB}$ & $20.12 \mathrm{aA}$ & $20.23 \mathrm{aA}$ & $20.89 \mathrm{aB}$ & $20.74 \mathrm{aB}$ \\
\hline \multirow{4}{*}{$\frac{\stackrel{Ð}{\varrho}}{\sum_{>}}$} & Wood $^{\text {ns }}$ & $84.05 \mathrm{aA}$ & $84.81 \mathrm{aA}$ & $85.11 \mathrm{aA}$ & $84.06 \mathrm{aA}$ & $84.52 \mathrm{aA}$ \\
\hline & Bark & $71.76 \mathrm{cD}$ & $74.78 \mathrm{abC}$ & $73.47 \mathrm{bcC}$ & $75.88 \mathrm{aB}$ & $69.35 \mathrm{dD}$ \\
\hline & Leaves & $75.60 \mathrm{aC}$ & $75.74 \mathrm{aC}$ & $74.75 \mathrm{abC}$ & $71.51 \mathrm{cC}$ & $73.34 \mathrm{bC}$ \\
\hline & Branches $^{\text {ns }}$ & $77.45 \mathrm{aB}$ & $78.19 \mathrm{aB}$ & $78.17 \mathrm{aB}$ & $76.89 \mathrm{aB}$ & $77.77 \mathrm{aB}$ \\
\hline \multirow{4}{*}{$\begin{array}{l}\widehat{a} \\
\frac{1}{4} \\
\frac{1}{4}\end{array}$} & Wood & $0.38 \mathrm{aD}$ & $0.38 \mathrm{aD}$ & $0.29 \mathrm{abD}$ & $0.27 \mathrm{bD}$ & $0.34 \mathrm{abD}$ \\
\hline & Bark & $6.32 \mathrm{bcA}$ & $5.26 \mathrm{cA}$ & $8.86 \mathrm{aA}$ & $6.98 \mathrm{bA}$ & $9.78 \mathrm{aA}$ \\
\hline & Leaves $^{\mathrm{ns}}$ & $4.17 \mathrm{aB}$ & $4.04 \mathrm{aB}$ & $4.51 \mathrm{aB}$ & $4.83 \mathrm{aB}$ & $4.44 \mathrm{aB}$ \\
\hline & Branches $^{\text {ns }}$ & $1.55 \mathrm{aC}$ & $1.68 \mathrm{aC}$ & $1.59 \mathrm{aC}$ & $2.20 \mathrm{aC}$ & $1.70 \mathrm{aC}$ \\
\hline
\end{tabular}

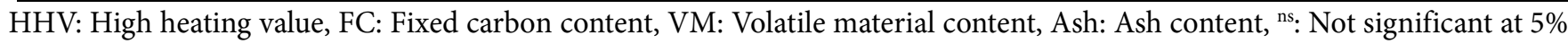
probability. Same lowercase letters in the same row do not differ between species for the same compartment, same uppercase letters in the same column do not differ statistically between compartments for the same species. 

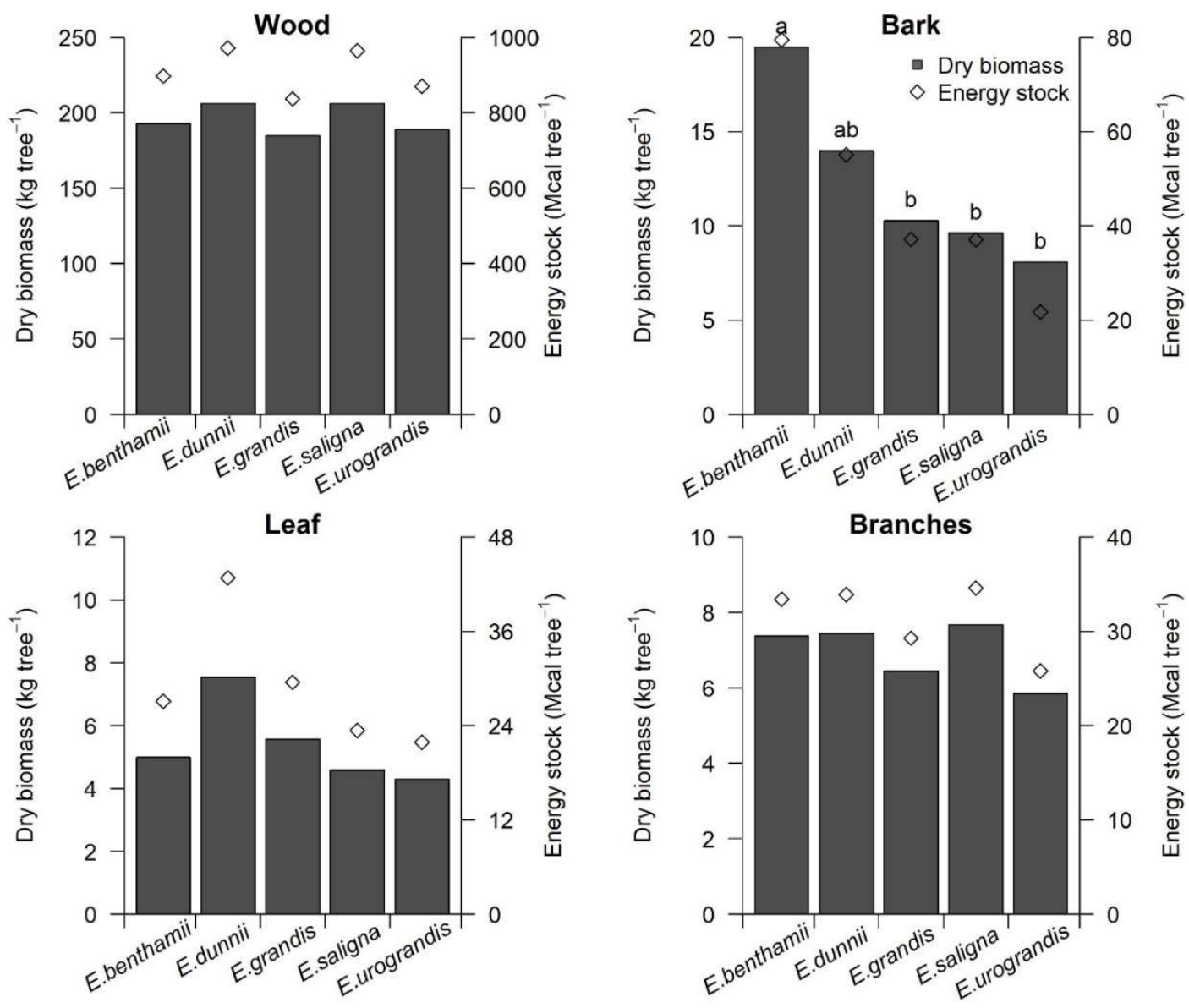

Figure 1. Dry biomass and energy stock in the different tree compartments.

Figura 1. Biomassa seca e estoque de energia nos diferentes compartimentos da árvore.

Materials with higher ash contents, such as bark and leaves, are not recommended for combustion in conventional boilers, since they can cause emissions of particulate matter in chimneys during the combustion process (BARRON, 1970; BRITO; BARRICHELO, 1978). In addition, slag and scale can be formed in burners and heat exchangers (PELANDA et al., 2015). The results found in this study corroborate the literature regarding the average values for fixed carbon and ash contents, so that the bark has values higher than those found for wood (BRITO; BARRICHELO, 1978; ELOY et al., 2015a, 2015b, VALE et al., 2002).

Volatile materials content affects positively in the ignition of solid fuels, facilitating the beginning of the process, however the burning is faster than fixed carbon (VIEIRA et al., 2013). The average for volatile materials are in accordance with those reported by Eloy et al (2016).
Regarding biomass production and energy stock per sample, there was no significant difference among species, except for the bark compartment. The species Eucalyptus benthamii presented the highest values for energy stock and biomass production in the bark compartment; however, the mean values for the species Eucalyptus dunnii did not differ statistically from the former or any other species (Figure 1).

In the evaluation of dry biomass production per hectare, Eucalyptus saligna and Eucalyptus dunnii stand out with a production of $219 \mathrm{Mg} \mathrm{ha}^{-1}$ and $225 \mathrm{Mg} \mathrm{ha}^{-1}$ for wood, which also present the highest values for energy stock, $1035 \mathrm{Gcal}$ ha ${ }^{1}$ and $1053 \mathrm{Gcal} \mathrm{ha}^{-1}$. In the bark, the highest values of dry biomass production and energy stock were observed for Eucalyptus benthamii, with $20.77 \mathrm{Mg} \mathrm{ha}^{-1}$ and $84.75 \mathrm{Gcal} \mathrm{ha}^{-1}$, respectively. This is due to the high percentage of bark in this species in relation to the others. For the compartment leaves, 
the highest values were observed in Eucalyptus dunni, with 8.03 $\mathrm{Mg} \mathrm{ha}^{-1}$ and $45.62 \mathrm{Gcal} \mathrm{ha}^{-1}$. In the compartment branches, species Eucalyptus dunnii, Eucalyptus grandis and Eucalyptus saligna presented the highest values for biomass in the range of 7.51 to $8.38 \mathrm{Mg} \mathrm{ha}^{-1}$; for energy stock, the values were between 34.13 and $37.78 \mathrm{Gcal} \mathrm{ha}^{-1}$ (Table 2).

In an experiment using Eucalyptus benthamii at one, two, three and four years of age, Silva et al. (2004) observed an increase in biomass allocation in the compartments wood and bark and, consequently, a decrease in the other two compartments (branches and leaves), with increasing age; the authors observed values of $70.4 \%, 7.3 \%, 15.2 \%$ and $7.1 \%$ for wood, bark, branches and leaves at four years of age, respectively.

The species Eucalyptus dunnii and Eucalyptus saligna presented superior results in relation to energy stock; they were the only ones among the studied species with an energy stock higher than $1000 \mathrm{Gcal} \mathrm{ha}^{-1}$ in the shaft, which is the most used compartment for power generation, since the compartments branches and leaves tend to be left in the field for nutrient cycling during forest harvest.

Table 2. Dry biomass and energy stock in the different tree compartments per hectare.

Tabela 2. Biomassa seca e estoque de energia nos diferentes compartimentos da árvore por hectare.

\begin{tabular}{|c|c|c|c|c|c|c|}
\hline & \multirow{2}{*}{ Variable } & \multicolumn{5}{|c|}{ Species } \\
\hline & & E. benthamii & E. dunnii & E. grandis & E. saligna & E. urograndis \\
\hline \multirow{8}{*}{ 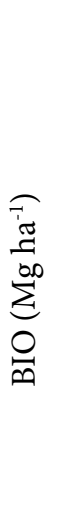 } & Wood & 205.8 & 219.89 & 215.28 & 225.23 & 205.06 \\
\hline & & $(85.8)$ & $(87.7)$ & $(89.2)$ & $(90.4)$ & (91.9) \\
\hline & Bark & 20.77 & 14.91 & 11.96 & 10.51 & 8.77 \\
\hline & & (8.7) & (5.9) & $(5.0)$ & $(4.2)$ & (3.9) \\
\hline & Leaves & 5.33 & 8.03 & 6.48 & 5.01 & 3.91 \\
\hline & & $(2.2)$ & $(3.2)$ & $(2.7)$ & $(2.0)$ & (1.8) \\
\hline & Branches & 7.86 & 7.94 & 7.51 & 8.38 & 5.38 \\
\hline & & (3.3) & (3.2) & (3.1) & (3.4) & $(2.4)$ \\
\hline \multirow{10}{*}{ 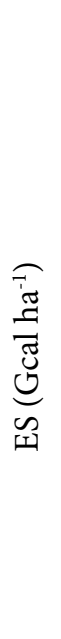 } & TOTAL & 239.73 & 250.78 & 241.24 & 249.15 & 223.12 \\
\hline & Wood & 956.73 & 1035.41 & 974.75 & 1053.33 & 944.71 \\
\hline & & $(86.5)$ & $(88.1)$ & $(89.7)$ & $(91.0)$ & (93.4) \\
\hline & Bark & 84.75 & 58.73 & 43.33 & 40.51 & 23.56 \\
\hline & & $(7.7)$ & $(5.0)$ & $(4.0)$ & (3.5) & $(2.3)$ \\
\hline & Leaves & 28.88 & 45.62 & 34.36 & 25.55 & 19.95 \\
\hline & & $(2.6)$ & (3.9) & $(3.2)$ & $(2.2)$ & $(2.0)$ \\
\hline & Branches & 35.60 & 36.13 & 34.13 & 37.78 & 23.50 \\
\hline & & $(3.2)$ & $(3.1)$ & $(3.1)$ & $(3.3)$ & $(2.3)$ \\
\hline & TOTAL & 1105.98 & 1175.90 & 1086.59 & 1157.19 & 1011.73 \\
\hline
\end{tabular}

BIO: Dry biomass, ES: Energy stock, Values in parentheses represent the percentage participation of the compartment in the total of the tree. 


\section{Conclusions}

Based on the results, it was possible to conclude that:

The different tree compartments presented characteristics that enable their energy use; however, this must be done carefully for bark and leaves, due to their high ash content;

Regarding biomass production and energy stock per species, there was no significant difference among species, except for the bark compartment;

More than $85 \%$ of the dry biomass and $86 \%$ of the energy stock of the tree are in the shaft; wood and bark are, respectively, the compartments with the greatest energy stock;

All species evaluated have a total energy stock higher than 1000 Gcal.ha $^{-1}$;

The wood of the shaft and branches does not present differences in relation to high heating value in the studied species.

\section{References}

ASSOCIAÇÃO BRASILEIRA DE NORMAS TÉCNICAS. NBR 8112 - Carvão vegetal: análise imediata Rio de Janeiro, 1986. $6 \mathrm{p}$.

ASSOCIAÇÃO BRASILEIRA DE NORMAS TÉCNICAS. NBR 8633 - Carvão vegetal: Determinação do poder calorífico superior Rio de Janeiro, 1984. 13p.

ASSOCIAÇÃO BRASILEIRA DE NORMAS TÉCNICAS. NBR 11941 Madeira - Determinação da densidade básica, 2003. 6p.

BARRON, A. Jr. Studies on the Collection of Bark char Throughout the Industry. TAPPI Journal, v. 53, n. 8, p. 1441 1448, 1970.

BRITO, J. O.; BARRICHELO, L. E. G. Características do eucalipto como combustível: análise química imediata da madeira e da casca. IPEF, v. 16, p. 63-70, 1978.

BOTREL, M. C. G.; TRUGILHO, P. F.; ROSADO, S. C. S.; MOREIRA DE SILVA, J. R. Seleção de clones de Eucalyptus para biomassa florestal e qualidade da madeira. Scientia Forestalis, v. 38, n. 86, p. 237-245, 2010.
DIAS JÚNIOR, A. F., JÚNIOR, C., ANDRADE, A. M. D., OLIVEIRA, E. D., LANA, A. Q. BRITO, J. O. Quality of Eucalyptus Wood Grown in Rio de Janeiro State for Bioenergy. Floresta e Ambiente, v. 23, n. 3, p. 435-442, 2016.

ELOY, E.; SILVA, D. A.; CARON, B. O.; SOUZA, V. Q. Capacidade energética da madeira e da casca de acácia-negra em diferentes espaçamentos. Pesquisa Florestal Brasileira. v.35, n. 82 , p. 163-167, 2015a.

ELOY, E.; SILVA, D. A.; CARON, B. O.; SOUZA, V. Q.; BEHLING, A.; ELLI, E. F.; MONTEIRO, G.C. Caracterização da biomassa da madeira e da casca de Mimosa scabrella Benth cultivada em dois diferentes espaçamentos. Ciência da Madeira (Brazilian Journal of Wood Science). v. 6, n. 1, p. 3846, 2015b.

ELOY, E., SILVA, D. A. D., SCHMIDT, D., TREVISAN, R., CARON, B. O., ELLI, E. F. EFFECT OF PLANTING AGE AND SPACING ON ENERGY PROPERTIES OF Eucalyptus grandis W. Hill EX Maiden. Revista Árvore, v. 40, n. 4, p. 749 $758,2016$.

EMPRESA BRASILEIRA DE PESQUISA AGROPECUÁRIA - EMBRAPA. Centro Nacional de Pesquisa de Solos. Sistema brasileiro de classificação de solos. Rio de Janeiro, 2006. $306 p$.

EMPRESA DE PESQUISA ENERGÉTICA - EPE, Balanço Energético Nacional. Ministério de Minas e Energia MME. Rio de Janeiro, RJ, 2014.

IBÁ. Indústria brasileira de Árvores. Anuário estatístico da IBA: ano base 2014. 2015, p. 100, 2015.

MALUF, J. R. T. Nova classificação climática do Estado do Rio Grande do Sul. Revista Brasileira de Agrometeorologia. v. 8, n. 1, p. 141-150, 2000.

PELANDA, K.; POTUSKI, D. C.; SILVA, D. A.; FERRAZ, F. A. Avaliação das possíveis implicações do uso de diferentes biomassas florestais como biocombustível em geradores de vapor. Ciência da Madeira (Brazilian Journal of Wood Science) v. 6, n. 2, p. 112-121, 2015.

RAMOS, L. M. A., LATORRACA, J. V. F., PASTRO, M. S., SOUZA, M. T., GARCIA, R. A., CARVALHO, A. M. Variação radial dos caracteres anatômicos da madeira de Eucalyptus grandis W. Hill ex Maiden e idade de transição entre lenho juvenil e adulto. Scientia Forestalis, v. 38, p. 411-418, 2011. 
R CORE TEAM. R: A Language and Environment for Statistical ComputingVienna, Austria, 2014. Disponível em: $<$ http://www.r-project.org/>.

SANQUETTA, C. R. Métodos de determinação de biomassa florestal. In: SANQUETTA, C.R. (Ed.). As florestas e o carbono. Curitiba, 2002. p. 119-140.

SANTANA, R. C.; BARROS, N. F.; LEITE, H. G.; COMEFORD, N. B.; NOVAIS, R.F. Estimativa de biomassa de plantios de eucalipto no Brasil. Revista Árvore, Viçosa, v. 32, n. 4, p. 697-706, jul./ago. 2008.

SILVA, H. D.; FERREIRA, C. A.; CORRÊA, R. S.; BELLOTE, A. F. J.; TUSSOLINI, E. L. Alocação de biomassa e ajuste de equações para estimativa de biomassa em compartimentos aéreos de Eucalyptus benthamii. Boletim de Pesquisa Florestal, Colombo, n. 49, p. 83-95, 2004

VALE, A. T.; MOURÃO, M. A.; LEÃO, B. A. L. Qualificação e caracterização energética da madeira e casca de espécies do cerrado. Ciência Florestal, v. 12, n. 1, p. 71-80, 2002.

VIEIRA, A.C.; SOUZA, S. N. M.; BARICCATTI, R. A.; SIQUEIRA, J. A. C.; NOGUEIRA, C.E.C. Caracterização da casca de arroz para geração de energia. Revista Varia Scientia Agrárias, v. 3, n. 1, p. 51-57, 2013. 